Acta vet. scand. 1988, 29, 245-248.

From the Department of Obstetrics and Gynaecology,

College of Veterinary Medicine, Hautjärvi, Finland.

\title{
Milk Progesterone Samples in Identifying Cycling Dairy Cows
}

\author{
By K. Heinonen, K. Rantasalmi and M. Alanko
}

\begin{abstract}
Heinonen, K., K. Rantasalmi, and M. Alanko; Milk progesterone samples in identifying cycling dairy cows. Acta vet. scand. 1988, 29, 245-248. - The purpose of this study was to determine the optimal interval between 2 consecutive milk progesterone samples for the detection of cyclicity in dairy cows. Two hundred and thirty-six postpartum periods were monitored with thrice-weekly whole milk progesterone assay. Cyclicity was determined from elevation of the progesterone level. Animals which had started to cycle by 50 or 60 days post partum were included in the study. The last of the 2 samples was taken at 50 or 60 days post partum, respectively.

The lowest percentage of false diagnoses $(\mathbf{9 . 0 \%})$ in cows which had started to cycle by $\mathbf{5 0}$ days post partum was obtained when the samples were taken at 8 days' interval. In cows which had started to cycle by 60 days post partum the lowest percentage of false diagnoses $(1.1 \%)$ was obtained when the samples were taken at 10 days' interval.
\end{abstract}

postpartum anoestrus; short cycles.

\section{Introduction}

Luteal function in the ovaries of dairy cows is reported to begin 17-30 days post partum (King et al. 1976, Webb et al. 1980, Fonseca et al. 1983, Larsson et al. 1984, Heinonen et al. 1988). However, roughly $10 \%$ of cows do not start to cycle (show no luteal function) until 50 days post partum (Larsson et al. 1984, Heinonen et al. 1988).

Acyclicity may be an indication of postpartum anoestrus (true anoestrus), ovarian follicular cysts or uterine involution disturbances. Early diagnosis of any of these disorders is essential if a calving interval of 1 year is to be maintained. In the case of true anoestrus, the average time from diagnosis and treatment to pregnancy is reported to be about 50 days (Alanko \& Pyörälä 1980), and in case of ovarian cysts 30-40 days (Alanko et al. 1980, Koppinen et al. 1984).
Milk progesterone assay can be used as an aid to identify acyclic animals without clinical examination. Elevated progesterone values are a strong indication of cyclicity. Because progesterone values vary according to the stage of the cycle, at least 2 consecutive samples are required for diagnosis. If one or both samples are elevated, the animal can be regarded as cycling. In a cycling cow with a cycle length of 21 days, progesterone values are elevated for approximately 14 days and low values can be detected for 7 days. Elevated values should therefore be detected if 2 samples are taken 7-10 days apart. However, in postpartum dairy cows cyclicity often begins with a corpus luteum of a short (5-10 day) lifespan (Morrow et al. 1969, Fonseca et al. 1983, Larsson et al. 1984, Heinonen et al. 1988). In case of short cycles it is questionable whether the sample interval of 7-10 days is optimal. The purpose of this paper was to study 
the accuracy of 2 consecutive progesterone samples in identifying cyclicity and to determine the optimal interval between samples.

\section{Material and methods}

The postpartum periods of 173 dairy cows were monitored with thrice weekly milk progesterone samples. Material I consisted of 147 postpartum periods of 84 Ayrshire and Friesian cows following their first and second calvings on an experimental farm (Heinonen et al. 1988). Material II consisted of 89 postpartum periods of 89 Ayrshire cows (age 2-8 years) on 20 different commercial farms (Gröhn et al. 1987). Milk samples were taken after milking every Monday, Wednesday and Friday from 14 to $\mathbf{7 0}$ days after calving. Progesterone was assayed with a commercial RIA kit (Whole Milk Progesterone RIA, Farmos Diagnostica Finland, Laitinen 1983).

Clinical examination of the animals was performed 3 times a week between parturition and the first insemination in material $I$, and at 1 and 4 weeks post partum in material II. In material I only cows with spontaneous resumption of cyclic ovarian activity were included; animals treated for ovarian cysts were excluded. Animals not cycling by 60 days post partum were excluded from further computations.

Milk progesterone values of $\geq 8 \mathrm{nmol} / \mathrm{l}$ were regarded as indicative of luteal function. The progesterone value at 50 or 60 days post partum and a further value 2-16 days earlier were registered for each postpartum period. Progesterone values were recorded on the computer as high ( $\geq 8 \mathrm{nmol} / \mathrm{l})$ or low ( $\leq 8 \mathrm{nmol} / \mathrm{l})$. Samples studied at 50 days post partum and earlier were taken only from cows which had started to cycle by 50 days post partum. Samples studied at 60 days post partum and earlier were taken only from cows which had started to cycle by 60 days post partum. The percentage of pairs of samples for which both values were low were computed for each sample interval; such cases were regarded as false diagnosis of acyclicity.
The statistical significance of the differences in porportions of false diagnoses was evaluated with the chi-square test.

\section{Results}

Eighty-three per cent $(83.1 \%)$ of all cows had started to cycle by 50 days and $90.0 \%$ by 60 days post partum.

The proportion of false diagnoses of acyclicity was equal in materials I and II for all sample intervals $(p>0.1)$. The lowest percentage of false diagnoses when the last sample was taken at 50 days post partum was $9.0 \%$ at a sample interval of 8 days. The percentages at sample intervals of 4,6 , 10 and 12 days were not significantly different from those at 8 days' interval $(p>0.1)$. When the last sample was taken at 60 days post partum, the lowest percentage of false diagnoses was $1.1 \%$ at an interval of 10 days, and no significant difference was noted between the percentages at $6,8,10$ and 12 days' interval $(p>0.1)$. The results are presented in Fig. 1.

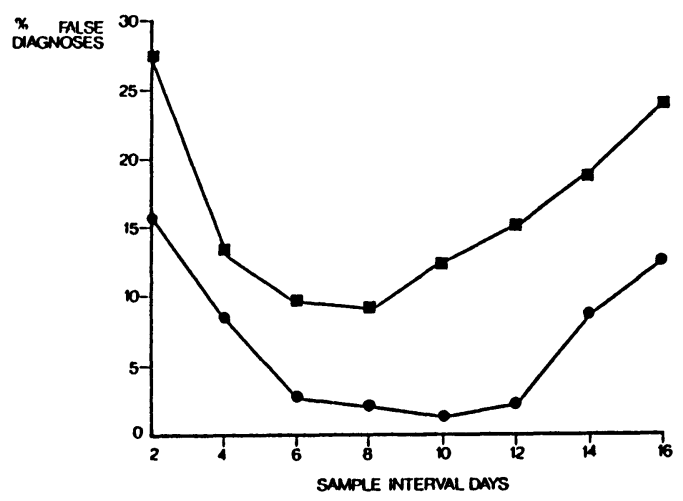

Figure 1. Proportion of false diagnoses of acyclicity from two consecutive milk progesterone samples in cows

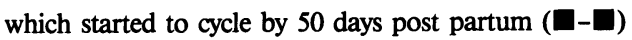
and 60 days post partum (-). Last sample taken at 50 days post partum and 60 days post partum, respectively. 


\section{Discussion}

The lowest percentage of false diagnoses was obtained by taking two milk progesterone samples at 8 (4-12) days' interval when diagnosing cyclicity at 50 days post partum, and at 10 (6-12) days' interval when making the diagnosis at 60 days post partum. The higher proportion (9\%) of false diagnoses in early post partum compared with that $(1 \%)$ in later post partum indicates that 2 samples are insufficient to accurately detect elevated progesterone levels during the first short cycles that follow parturition, a phenomen which occurred frequently in the present material ( $\mathrm{Hei}$ nonen et al. 1988). This could be harmful, particularly in herds in which onset of cyclicity is delayed and in which the first cycles occur late after parturition. However, the frequency of short cycles seems to be low in cows which start to cycle late (Larsson et al. 1984). In the present material $60 \%$ of the cows which were acyclic at 50 days post partum started to cycle by 60 days post partum, which indicates that the earlier the diagnosis is made, the higher the spontaneous recovery rate of cyclicity is likely to be. Thus in field conditions the diagnosis of acyclicity by 60 days post partum appears optimal; a diagnosis made later than this leaves little time for therapeutic procedures, while a premature diagnosis entails the unnecessary investigation of a certain number of animals.

However, it should be borne in mind that cows which start to cycle but for some reason cease to do so and cows which have a persistent corpus luteum may inadvertently be diagnosed as cycling if milk samples are used.

The effective sample interval of 6-12 days enables the herdsman to obtain the results of the first sample before taking the second. In the case of an elevated value in the first sample, additional sampling is unnecessary.

It is concluded that taking 2 milk progesterone samples at 10 days' interval (50 and 60 days post partum) proved to be an applicable and accurate method of routine detection of cyclicity in the present material.

\section{References}

Alanko $M$, Pyörälä S: The treatment of anestrus and subestrus in dairy cattle using PRID or gonadotrophins. Nord Vet.-Med. 1980, 32, 444-452.

Alanko M, Katila T. Treatment of cystic ovaries in dairy cattle using human chorionic gonadotrophin or a compound consisting of human chorionic gonadotrophin with progesterone. Nord Vet.-Med. 1980, 32, 122-127.

Fonseca FA, Britt JH, McDaniel BT, Wilk JC, Rakes $A H$ : Reproductive traits of Holsteins and Jerseys. Effects of age, milk yield and clinical abnormalities on involution of cervix and uterus, ovulation, estrous cycles, detection of estrus, conception rate and days open. J. Dairy Sci. 1983, 66, 1128-1147.

Gröhn $Y$, Heinonen $K$, Lindberg $L-A$ : Fat infiltration in the liver of Finnish Ayrshire cows during early lactation. Acta vet. scand. 1987, 28, 143-149.

Heinonen $K$, Miettinen $P$, Savolainen $E$, Tuovinen $V$, Alanko $M$ : Postpartum reproductive functions in Finnish Ayrshire and Friesian cows after three subsequent parturitions. Acta vet. scand. 1988, 29, preprint.

King GJ, Hurnik JF, Robertson HA: Ovarian function and estrus in dairy cows during early lactation. J. Anim. Sci. 1976, 42, 688-692.

Koppinen J, Vesanen M, Alanko M: Ovarian cysts in diary cattle - Some aspects of diagnosis, treatment with GnRH and HCG and subsequent Milk Progesterone Values. Nord. Vet.-Med. 1984, 36, 26-31.

Laitinen J: Oestrus confirmation, pregnancy diagnosis and post-partum follow up of the Finnish diary cows by milk progesterone assay: Effect of breed, season, feed and sampling on milk progesterone levels. Publications of the University of Kuopio Natural Sciences Original Reports 1983, 1, 39-40.

Larsson K, Jansson L, Berglund B, Edqvist L-E, Kindahl $H$ : Postpartum reproductive performance in dairy cows I: Influence of animal, breed and parity. Acta vet. scand. 1984, 25, 445-461.

Morrow DA, Roberts SJ, McEntee K: Postpartum ovarian activity and involution of the uterus and cervix in dairy cattle. 1 . Ovarian activity. Cornell Vet. $1969,59,173-189$.

Webb $R$, Lamming GE, Haynes NB, Foxcroft GR: Plasma progesterone and gonadotrophin concentrations and ovarian activity in post-partum dairy cows. J. Reprod. Fert. 1980, 59, 133-143. 


\section{Sammenfatning}

Progesteronprov ur mjölk föt att bestämma cykliciteten hos mjölkkor.

Avsikten med denna undersökning var att bestämma det optimala intervallet mellan två på varandra följande progesteronprov för att kunna detektera mjölkkors cyklicitet. Tvåhundratrettiosex postpartuma perioder undersöktes. Progesteronproven togs tre gånger per vecka ur helmjölk. Cykliciteten bestämdes på basen av förhöjningar ac progesteronvärdet. Till undersökningen togs djur vars förökningscykel startat inom 50 eller 60 dagar postpartumt. De två sista proven togs, i respektive grupper, 50 eller 60 dagar postpartumt.

Den lägsta procenten felaktga diagnoser $(\mathbf{9 \%})$ hos kor vars förökningscykel börjat inom 50 dygn postpartumt, uppnåddes då progesteronproven togs med 8 dygns mellanrum. Bland kor som påbörjat sin cykel inom 60 dygn postpartumt uppnåddes den lägsta procenten felaktiga diagnoser $(1,1 \%)$ då proven togs med 10 dygns intervall.

\section{(Received December 10, 1987).}

Reprints may be requested from: Kalevi Heinonen, Department of Obstetrics and Gynaecology, College of Veterinary Medicine, SF-04840 Hautjärvi, Finland. 